\title{
Shall COVID-19 accelerate the transfer of passive learning to active education?
}

\section{¿Logrará la COVID-19 acelerar la transición del aprendizaje pasivo a la educación activa?}

\author{
Jan Feyen \\ Professor Emeritus, Catholic University of Leuven, Belgium. \\ Corresponding author: jan.feyen@kuleuven.be
}

Wisdom is gathered from the bruises and bumps and the beautiful moments of life. The corona crisis is such a tipping point for the world. The crisis is like a tsunami which we have to go through together. Citizens are all dazed-looking around at what is causing the corona pandemic, and the situation two to three months after the outbreak indicates that the end of the crisis is far from out of sight. First, it was China, then Europe, then the United States, and now more recently the battlefield of the coronavirus is called Latin America. It is to be expected that the virus will leave more scars on this continent, given that Latin America always has been a continent of structured chaos, corruption, crime, and authoritarian regimes. Without the slightest scruples, the virus and the lockdown are exploited to push through the personal agenda and the settling of disputes.

To illustrate previously, I just refer to the World Wide Fund for Nature (WWF), who recently released a study on the condition of the rainforests. In March, the month when corona really decomposed all its devils, its surface area shrank worldwide by 6,500 square kilometers, 150 percent more than the same month in 2019. South America is the leader in forest logging, where deforestation rose by a staggering 167 percent. Jair Bolsonaro, President of Brazil, quietly continued to tap off the environmental services to protect the Amazon and step up military raids against gangs in the favelas. While his country is the second most COVID-19 affected in the world, Bolsonaro is busy behind the scenes pushing through a law that seems to suit companies seeking to seize parts of the protected reserves of indigenous people. Another example is Colombia, where the right-wing president Ivan Duque had promised to stop forest logging in exchange for millions of European aid. But now that this operation has been forced off by corona, deforestation is increasing. In Bolivia, the situation under interim president Jeanine Áñez is not much better. She favors deforestation and does nothing to stop the corona clear cut. At the beginning of this year, she allowed nearly 10 million hectares of previously protected forest to be burned down in a controlled manner for the agro-business. Since the outbreak, she arrested 67 people, so-called for destabilization and crimes against public health, not accidental political opponents. Many more examples could be given to illustrate that in Latin-America the corona pandemic is misused by the leaders often for their own profit and/or for strengthening their position.
La sabiduría viene de golpes y magulladuras, así como de los hermosos momentos de la vida. La pandemia de la COVID-19 es un punto de inflexión para el mundo. La crisis es como un tsunami que tenemos superar juntos. Los ciudadanos miramos aturdidos las consecuencias de la pandemia, y la situación, dos o tres meses después del brote, indica que el final de la crisis se encuentra lejos. Primero fue China, luego Europa y Estados Unidos, y más recientemente el campo de batalla del coronavirus se llama América Latina. Es de esperar que el virus deje más cicatrices en este continente, dado que América Latina siempre ha sido un continente de caos estructurado, corrupción, delincuencia y regímenes autoritarios. Sin el menor escrúpulo, el virus y la cuarentena se explotan para impulsar agendas personales e iniciar disputas.

Como muestra solo basta citar al Fondo Mundial para la Naturaleza (WWF), que recientemente publicó un estudio sobre la condición de los bosques tropicales. En marzo, el mes en que el coronavirus liberó a todos sus demonios, su superficie se redujo en todo el mundo en $6,500 \mathrm{~km}^{2}$, un $150 \%$ más que en el mismo mes de 2019. América del Sur es el líder en la tala forestal, aquí la deforestación aumentó un asombroso 167\%. Jair Bolsonaro, presidente de Brasil, al mismo tiempo que intensificó las incursiones militares contra las pandillas en las favelas, continuó con sigilo inutilizando los servicios ambientales que protegen el Amazonas. Si bien su país es el segundo más afectado por COVID-19 en el mundo, tras bastidores Bolsonaro está ocupado impulsando una ley que parece adaptarse a las empresas que buscan confiscar partes de las reservas protegidas de los pueblos indígenas. Otro ejemplo es Colombia, donde el presidente derechista Iván Duque había prometido detener la tala forestal a cambio de millones de ayuda europea. Sin embargo, justo ahora que esta operación habría sido ideal debido a la crisis por el coronavirus, la deforestación en dicho país está aumentando. En Bolivia, la situación bajo la presidencia interina de Jeanine Áñez no es mejor. Ella favorece la deforestación y no hace nada claro para frenar la crisis del coronavirus. Con la excusa del impulsar el agronegocio, a principios de este año, ella permitió que se quemaran de manera controlada casi 10 millones de hectáreas de bosques previamente protegidos. Desde el brote, arrestó a 67 personas por supuestos cargos de desestabilización y crímenes contra la salud pública, opositores políticos no accidentales. Se podrían dar muchos más ejemplos para ilustrar que en América Latina la pandemia está siendo utilizada muy frecuentemente para el beneficio propio de líderes y/o para fortalecer su posición. 
Unfortunately, the associated health, socio-cultural, and economic consequences of the corona crisis make the majority of the people feel hopeless. The mortality burden by COVID-19 is considerable and tends to be higher in older populations. It is only with the recession of the crisis, after several months of lockdown, that we will realize the devastating socio-economic impact. The predictions for socio-economic recovery vary from six months to three years. Worldwide, many small to medium-sized companies will go bankrupt, many people will lose their job and will no longer be able to pay the basic needs, and graduating students will not easily find employment. However, we should as far as possibly leave the hopeless feeling of the crisis behind us and use the crisis to refocus and give new impulses to the society and ourselves. For example, governments must, among other things, work towards a fair socio-economic distribution. If no fair redistribution in society is pursued, this will result in a mortgage on our future? It is to be hoped that in the coming years national budget deficits will not result in savings in sectors such as health, education, culture, and to some extent environment and climate.

However, it is to be feared that education and culture will temporarily fall victim to the government's austerity, who will primarily support the revival of the economic sectors. In this regard, it is worth mentioning that in the middle of the coronavirus pandemic, when the Ecuadorian government decided that education should continue via live streaming, Mr. Vinicio Baquero, vice-minister of Education Management, irrevocably offered his resignation. According to his vision "the discourse of quality and inclusive education without appropriate resources is no more than an aggregate of utopian thoughts and vain words". It is of course true with too little financial support becomes the provision of good education problematic. Quality education is more than needed in the knowledge and learning society because it constitutes a critical factor in innovative developments, and the processes of social, cultural, and economic development. In these difficult days, it constitutes what society needs more than ever before.

Perhaps it is good to dwell a bit on what is understood by quality education taking into consideration that in many countries higher education still results in a passive learning behavior of the students. Traditionally for economic reasons and to reduce the teaching load of the academic staff to a reasonable level is teaching where possible offered to large groups of students. Particular in the first basic years of higher education are similar courses organized over the boundaries of the faculties. The main complaint of this type of education is that the teacher has little to no interaction with the students and that the method results in passive learning behavior. Students to be able to cope with the challenges of the 21 st century should be subdued to the process of active learning. Active learning is the method that engages students in the learning process, it is students must do more than just listen, they must read, write, discuss, be engaged in solving problems, develop a collaborative spirit, interpersonal and communication skills, and be prepared for lifelong learning. Although today technological devices exist that enables the professor to interact with 200 or more students in a large auditorium, the configuration of a large aula neither permits active collaboration among students, nor between the students and the professor. Therefore, we might maintain the classroom configuration
Desafortunadamente, las consecuencias económicas, socioculturales y económicas asociadas con la crisis del coronavirus hacen que la mayoría de las personas se sientan sin esperanza. La mortalidad por COVID-19 es considerable y mayor en poblaciones de mayor edad. Solo con la recesión de la crisis, después de varios meses de encierro, nos daremos cuenta del devastador impacto socioeconómico. Las predicciones para la recuperación socioeconómica varían de seis meses a tres años. En todo el mundo, muchas pequeñas y medianas empresas quebrarán, muchas personas perderán su trabajo y ya no podrán pagar sus necesidades básicas, y los recién graduados no encontrarán fácilmente un empleo. Sin embargo, deberíamos, en la medida de lo posible, dejar atrás el sentimiento de desesperanza de la crisis y utilizarla para reenfocarnos y dar nuevos impulsos a la sociedad y a nosotros mismos. Por ejemplo, los gobiernos deben, entre otras cosas, trabajar por una distribución socioeconómica justa, pues no hacerlo significará hipotecar aún más nuestro futuro. Cabe esperar que en los próximos años los déficits presupuestarios nacionales signifiquen cero ahorros para sectores como la salud, la educación, la cultura y, en cierta medida, el medio ambiente y el clima.

Aún más, es de temer que la educación y la cultura sean víctimas de la austeridad de muchos gobiernos, quienes privilegiarán la reactivación de los sectores económicos. En este sentido, vale la pena mencionar que, en medio de la pandemia de coronavirus, cuando el gobierno ecuatoriano decidió que la educación debería continuar en la modalidad online, Vinicio Baquero, viceministro de Gestión de la Educación, ofreció irrevocablemente su renuncia. Según su visión "sin recursos, el discurso de una educación de calidad e inclusiva no pasa de ser un agregado de pensamientos utópicos y palabras vanas". Esto es cierto, con poco apoyo financiero, la provisión de buena educación se vuelve problemática. En la sociedad del conocimiento y el aprendizaje, una educación de calidad es más que necesaria porque constituye un factor decisivo en el desarrollo innovador y en los procesos de desarrollo social, cultural y económico. Algo que nuestra sociedad necesita más que nunca estos días difíciles.

Teniendo en cuenta que en muchos países la educación superior aún se fundamenta en una metodología de aprendizaje pasivo de los estudiantes, quizás convenga analizar brevemente lo que se entiende por educación de calidad. Por razones económicas y para reducir la carga docente a un nivel razonable, tradicionalmente la enseñanza se ofrece, siempre que sea posible, a grandes grupos de estudiantes. Especialmente en los primeros años de la educación superior, se organizan cursos comunes, sobre los límites físicos de las Facultades. La principal queja de este tipo de educación es que el docente tiene poca o ninguna interacción con los estudiantes y que el método da como resultado un comportamiento de aprendizaje pasivo. Sin embargo, para poder enfrentar los desafíos de este siglo, los estudiantes deben someterse a un proceso de aprendizaje activo. El aprendizaje activo es el método que involucra a los estudiantes en el proceso de aprendizaje, a más de escuchar, los estudiantes deben leer, escribir, discutir, participar en la resolución de problemas, desarrollar un espíritu de colaboración, habilidades interpersonales y de comunicación, y estar preparados para el aprendizaje de por vida. Aunque hoy existen dispositivos tecnológicos que permiten al profesor interactuar con 200 o más estudiantes en un auditorio grande, la configuración de dicho auditorio no permite la 
which still is mostly applied in Ecuador's HEIs, change the set-up of the multiple desks facing the whiteboard to an arrangement whereby every student can see and hear one another. Whereas this approach favors the development of an active learning attitude, the main drawback is when the number of students following a specific course rise up to 200 or more, that the group of students has to be split into at least 10 groups of 20 students, with the burden for the professor to repeat 10 times or more the same class, which automatically will result to an increase of the professors' teaching hours, making higher education more costly and less efficient.

Unfortunately, CES/SENESCYT recently increased the teaching load for full-, half- and part-time professors given the recent drop in national revenue caused by the corona crisis and the crashing of the international oil price. The minimum number of teaching hours in a week for a fulltime professor will increase from 3 to 14 hours $(+367 \%)$ and the maximum teaching load will rise from 16 to 26 hours $(+62.5 \%)$. With such an increase in teaching load full-time professors will not have much time and motivation to invest in research or other activities, so important in the modernization process of the current mainly passive education system. The main challenge Ecuador's HEIs, like the HEIs in other countries, faces is how to convert given the current lousy economic situation (the budget cut for the HEIs is expected to be of the order of $10 \%$; which based on the 2020 budget year, for UC will correspond to a reduction of the order of 5.6 million USD) the passive education system to an active learning mode, ensuring at the same time that the educational burden of the teaching staff remains realistic and permits the staff to allocate sufficient time to research and social services and activities.

Could under the current conditions the transfer from passive to active education be realized via online teaching, also called live streaming, and video learning? The lockdown recently forced educational institutions to online teaching, with a lot of problems due to the lack of technology and efficacious tools, and the fact that neither the teaching staff nor the students were prepared. Virtual and online education is a reality as we enter daily further the so-called network society of the $21^{\text {st }}$ century. It is now more accessible and considered by many a better option than the traditional education system of universities and colleges. It is generally accepted that digital education generates new learning opportunities as students engage in online, digital environments and as faculty change educational practices through the use of hybrid courses, personalized instruction, new collaboration models, and a wide array of innovative engaging learning strategies. However, just like anything else, there are pros and cons of online education. The challenge for the HEIs in general, and UC in particular, will be how to implement and organize blended learning, it is mixing classroom teaching with online education and video learning.

There are a lot of educational videos available and their number in many educational fields is growing daily. Why not partially replace the classic teaching by online teaching and educational videos avoiding the academic staff to spend a lot of time in the preparation of lectures and the teaching of the material? Doing so would permit offering in a very economical way a class (e.g., the theoretical basis of the course) in one time to a large group of students, while the hours in class could be used to discuss in smaller groups the taught material, conduct colaboración activa entre estudiantes, ni entre estudiantes y profesor. Por esto, se podría mantener la configuración del aula que comúnmente aún se aplica en las IES de Ecuador, pero con la condición de cambiar la configuración de los pupitres frente a la pizarra a una en la cual los estudiantes puedan verse y escucharse entre sí. Sin duda este enfoque favorece el desarrollo de una actitud de aprendizaje activo, pero el principal inconveniente surge cuando el número de estudiantes de un curso específico se eleva a 200 o más. En dicho caso el grupo de estudiantes tendría que dividirse en al menos 10 grupos de 20 estudiantes, con la consecuente carga para el profesor, quién deberá repetir la misma clase 10 veces o más, lo que automáticamente resultará en un aumento de las horas de enseñanza docente, haciendo que la educación superior sea más costosa y menos eficiente.

Desafortunadamente, debido la reciente baja de ingresos nacionales causada por la crisis del coronavirus y la caída del precio internacional del petróleo, CES / SENESCYT recientemente aumentó la carga horaria de enseñanza para profesores de tiempo completo, medio y parcial. El número mínimo de horas semanales de enseñanza para un profesor a tiempo completo aumentará de 3 a 14 horas (+ $367 \%$ ) mientras que la carga máxima de enseñanza aumentará de 16 a 26 horas $(+62.5 \%)$. Con tal aumento, los profesores a tiempo completo no tendrán mucho tiempo y motivación para invertir en investigación u otras actividades, tan importantes en el proceso de modernización del actual, principalmente pasivo, sistema educativo. El principal desafío al que se enfrentan las IES de Ecuador, así como las de otros países, es cómo realizar la transición, dada la pésima situación económica actual (se espera que el recorte presupuestario para las IES ecuatorianas sea del orden del $10 \%$; del presupuesto 2020 , uno recorte de 5.6 millones de USD para la UC), de un sistema de educación pasiva a un modelo de aprendizaje activo, asegurando al mismo tiempo que la carga horaria de docencia siga siendo realista y permita los académicos dispongas de suficiente tiempo para investigar y brindar servicios y actividades sociales.

En las condiciones actuales, ¿será posible la transición de la educación pasiva a la activa a través de la enseñanza en línea o video aprendizaje? El cese de actividades obligó recientemente a las instituciones educativas a enseñar en línea, con muchos problemas debido a la falta de tecnología y herramientas efectivas, y al hecho de que ni el personal docente ni los estudiantes estaban preparados. No obstante, la educación virtual y en línea es una realidad a medida que ingresamos diariamente a la llamada sociedad de red del siglo XXI. En la actualidad es más accesible y considerada por muchos como la mejor opción frente al sistema educativo tradicional de universidades y colegios presenciales. En general, se acepta que la educación digital crea nuevas oportunidades de aprendizaje a medida que los estudiantes participan en entornos digitales en línea y los maestros cambian las prácticas educativas mediante el uso de cursos híbridos, instrucción personalizada, nuevos modelos de colaboración y una amplia gama de estrategias de aprendizaje innovadoras y atractivas. Sin embargo, al igual que cualquier otra cosa, la educación en línea ofrece también desventajas. El desafío para las IES, y para la UC en particular, será cómo implementar y organizar el aprendizaje híbrido: la combinación de la enseñanza en el aula con la educación en línea y el video aprendizaje. 
group projects, oblige the students to collaborate, focus on the development of problem-solving skills, etc. In contradiction to the passive learning type of classroom where the teachers are the leaders, in the discussion and project sessions, the students should lead the process, and the professors fulfill the role of coach.

The successful implementation of live streaming teaching not only requires the availability of the technology, but it also requires that the academic staff receives training in online teaching, the development of digital course material, and the coaching of the students during online and work sessions. Additionally, it is a must that docents teaching a given curriculum in different faculties develop the digital course material together and that colleagues of the departments of pedagogy and computer sciences provide assistance. Furthermore, the virtual mode of teaching also requires that the students at home have access to the internet and possess a laptop, enabling them to follow from home via internet class sessions and the downloading and viewing of educational videos. The use of digital English educational curricula and videos, material that worldwide is more available, offers the advantage that the students in an early phase of their educational program, when confronted herewith, will learn parallel to the course material the English language. An additional asset, because being able to read English is a tremendous advantage in developing the thesis and the reading of research papers.

The implementation of online teaching and video learning in combination with class sessions for group discussion and project work will not only engage the students in the learning process but if well-organized it will enable the HEIs to cope with the current rationing of government funding without being a hinder in the development, improvement, and delivery of quality education. And quality education is more than ever before needed to generate the new generation of graduates who will be able to cope with the multiple challenges of the 21 st century, such as health pandemics, the replacement of passive education partially with online teaching, adaptation to climate change, ending of forest logging and the promotion of ecosystem conservation, dropping pollution and the recycling of waste, turning authoritarian systems into democracies, working towards a more equal distribution of welfare, etc.

In summary, shall COVID-19 inspire Ecuador's HEIs to speed-up the move from the classical classroom to the Web, and turn the classical classroom sessions into a variety of active learning activities, facilitating the transfer of passive learning to active education? Additionally, I wonder if the pandemic will turn society into a more livable and peaceful place, not only for a few but for the entire community?
Hay muchos videos educativos disponibles en línea y su número crece a diario en diversos campos educativos. ¿Por qué no reemplazar parcialmente la enseñanza clásica por la enseñanza en línea y mediante estos videos, evitando así que el personal académico dedique demasiado tiempo a la preparación de conferencias y la enseñanza del material? Hacerlo permitiría ofrecer de una manera muy económica una clase (e.g., la base teórica del curso) y al mismo tiempo a un gran grupo de estudiantes, mientras que las horas en clase podrían usarse para discutir en grupos más pequeños el material enseñado, conducir proyectos grupales, obligar a los estudiantes a colaborar, a enfocarse en el desarrollo de habilidades para resolver problemas, etc. En estas sesiones de proyectos y de discusión, los estudiantes se forjarán como líderes del proceso de aprendizaje, mientras que el profesor cumplirá el papel de entrenador.

La implementación exitosa de clases virtuales no solo requiere de la disponibilidad de la tecnología, sino también que el personal académico reciba capacitación en enseñanza en línea, sobre el desarrollo de material digital del curso y la capacitación de los estudiantes durante las sesiones en línea y de trabajo. Además, es imprescindible que docentes que enseñan en diferentes facultades, pero que comparten un mismo plan de estudios, desarrollen juntos el material del curso digital, y que los colegas de los departamentos de pedagogía y ciencias de la computación brinden asistencia. El modo virtual de enseñanza también requiere que los estudiantes en el hogar tengan acceso a Internet y posean una computadora portátil, lo que les permita seguir desde sus hogares, clases virtuales y la descarga y visualización de videos educativos. El uso de programas y videos educativos digitales en inglés, material mayormente disponible a nivel mundial, ofrece la ventaja de que los estudiantes en una fase temprana de su programa educativo, cuando se enfrentan a este tipo de actividades, aprenderán en paralelo al material del curso y también el idioma inglés. Un activo extra, porque poder leer inglés es una gran ventaja en el desarrollo de la tesis y la lectura de artículos de investigación.

La implementación de la enseñanza en línea y el video aprendizaje, en combinación con sesiones de clase para la discusión grupal y el trabajo del proyecto, no solo involucrará a los estudiantes en el proceso de aprendizaje, sino que, si está bien organizado, permitirá a las IES hacer frente al racionamiento actual de los fondos gubernamentales sin ser un obstáculo para el desarrollo, la mejora y la entrega de una educación de calidad. Y la educación de calidad es más necesaria que nunca para generar la nueva generación de graduados que podrán hacer frente a los múltiples desafíos del siglo XXI, como las pandemias de salud, el reemplazo de la educación pasiva, en parte con la enseñanza en línea, la adaptación al cambio climático, el fin de la tala forestal y la promoción de la conservación del ecosistema, la eliminación de la contaminación y el reciclaje de los desechos, convirtiendo los sistemas autoritarios en democracias, trabajando hacia una distribución más equitativa del bienestar, etc.

En resumen, ¿Inspirará la COVID-19 a las IES de Ecuador para acelerar el paso del aula clásica a la Web, y convertir las sesiones del aula clásica en una variedad de actividades de aprendizaje activo, facilitando la transferencia del aprendizaje pasivo a la educación activa? Además, me pregunto si la pandemia convertirá a la sociedad en un lugar más habitable y pacífico, no solo para unos pocos sino para toda la comunidad. 